\title{
Employee Loyalty and Its Impact on Hotel Growth
}

\author{
Jing Huang ${ }^{1, a^{*}}$ \\ ${ }^{1}$ Tianjin Maritime College, No.8,Yashen Raod, Jinnan District,Tianjin City,China \\ alily2019151412@163.com
}

\begin{abstract}
Keywords: Employee Loyalty; Customer Loyalty; Retention Span; Hotel Growth
\end{abstract}
\begin{abstract}
Quality services provided for customers by highly skilled and responsible hotel employees ensure customer retention and the success in running a hotel. This paper focuses on certain fundamental factors that need to be considered for retaining experienced and skilled employees to guarantee the healthy growth of the hotel businesses.
\end{abstract}

\section{Introduction}

At many hotels in major Chinese cities, the services are often degraded by the poor performances of the employees: they are physically there at work, but their minds are apparently not. Clerks just come and go: employee retention is pretty low except for the privileged few in the management. Those who choose to stay tend to lack motivation and enthusiasm in work. To the management of such hotels, employee loyalty is a luxury.

It is essential that employee loyalty contributes to a hotel's business operation and growth, because only loyal employees will take the initiative to provide high quality services to the customers, thereby gaining stability and even increasing patronage. But how can we improve employee loyalty? Through careful literature reading, it can be found that there is no one-fit-all approach to it and the following three tips crucial for loyalty improvement has been gathered. The methods will be discussed in the following.

\section{Identifying Prospective Loyal Employees in Recruitment Process}

The company takes a great deal of time, money and effort trying to make disloyal employees loyal and it may still fail as a result. Positive changing is difficult for an employee who is not inclined to be loyal. So the better way is to see if the employees are prospective loyal from the recruitment and decided if you want to hire them. What should the hotels do? There are some tips below.

Finding Traces of Prospective Loyalties from Resumes. After the human resource stuffs get the resumes, a careful reading and reviewing of the resume details can greatly help them to orientate prospective loyal employees. There are two aspects followed worth particular attention-employment length and job-hopping rate.

After a careful scan, the previous experiences of working of an applicant may consider as one of the conditions to indicate his future performance. In addition to the obvious mistakes record, also need to pay attention to job-hopping. If a candidate's resume shows it is quite frequently that he or she has hopped from job to job, it possibly means "you'll be searching for their replacement well before their annual review" (Mike Michalowicz, 2010). Therefore employment length and job-hopping frequency are the two valuable indicators of whether an applicant is prospective loyalty or not.

Using Well-designed Questions to Judge an Applicant's Loyalty. From what Michalowicz said, why does a job applicant give up his former job and how he comments on his former employer can give clues whether he will be a prospective loyalty in his new workplace even have an understanding of his personality. If most of the comments on him are positive or understandable, that he will be the good choice you want to hire. So asking some well-designed questions regarding the working experiences in the past is a smart approach. For example, ask the reason why applicant quit previous jobs? When the previous company faced some problems, have he had attempted to solve the troubles of the company before his quitting or without any effort. What comments he may 
give to his previous employers and the workplaces where he work. According to the comments he gives, it may provide hints on his personal characters and also help the human resource department to make the decision if you will hire him.

Providing the Right Candidate with the Appropriate Position Is a Drift Method--Factors Helping Employers to Make the Sensible Decisions in Recruitment. Maintaining a qualified and suitable employee loyalty for an expectant or even a reasonable length is really hard, especially when he has better offers from other companies which he thinks more fit him. What's more, during the downturn of global economy, there are many inestimable reasons to take a job. For instance, some people accept job offers simply because you give the only response to his apply, and he needs to feed his family. Such new employees may not necessarily be loyal to their jobs (Insala, 2007). What is worse, some employers who are short-sighted just keep an eye on the business expenses such as they recruit applicants just for filling the vacancies, also they would simply like to select the applicants who would accept relatively low pay no matter whether the applicants are qualified for the jobs and fit working environment (Petrecca 2011).As qualified employers, you should well understand how can make the employees loyal to them, the answer is working satisfaction and happy working hours in the new working environment (Hunter 2011).

Now there is a new question. How employers can forecast the employee' satisfaction and happiness? Rose and Gordon assumed and identified the five major influential reasons through data collection and analysis for employees to decide on job opportunities. The top five are 'job security', 'interesting work', 'work related to degree', 'career development' and 'location' (Rose \& Gordon 2010). Despite well designed interviews and questionnaires with all age group candidates, they still found the strong effects of these five major factors on during a candidate makes decision are clearly link with his age. Based on their findings, 'job security' and 'interesting work' retained their great concerning all the age groups, factors like 'career development' and 'work related to degree' have a decreasing influence with the age grow. 'Work location', understandably becomes increasingly important since the age of 30. This may be because most candidates over the age of 30 have a family who are reluctant to seek jobs with their families elsewhere, or leave their families to a fresh job far away their families.

In addition to the four major factors, Hasan suggested other set of factors which are also crucial to ensuring the prospective loyal employees recruitment. Those are, a proper wage, a good job recognition, team cooperation, participation in corporate decisions that employees' own benefit, personal accomplishment, working conditions, self-improvement, opportunities for getting promoted and professional growth and clear awareness the expectation of employers (Hasan 2007).

From this analysis, employers should not only consider their own needs and interests, but also the needs, interests and concerns of their candidates if they want to successfully recruit prospective loyal employees. Because the loyal employees are also great asset to a company. They should be treated as the resources of the hotels not just workers.

Good Reputation Record of A Company is a Strong Magnet to attract prospective loyal employees. The public praise you treat your employees in the past and present may also affect the quality of your recruitment. If a man is given a chance to choose a job among several companies, which company he will select or what factors he will consider? Most likely, he will choose the one with the best reputation and professional environment (RW Special Reports). Therefore, positive feedback from past and present employees is a crucial factor affecting the quality of company's recruitment.

\section{The Maintain of Long Retention Span and High Employee Loyalty}

To achieve the final goal-- building up a loyal team, a successful recruitment is only the beginning of it. Employers are faced with a large number of work to do for keeping the employees' long retention span and the team's high loyalty. After the study, at least three jobs below are required by the employer.

Offering On-the-post Training to Employees. Fresh employees may be easily get depressed, when he feels that no one really cares about his work and feel very lost that it seems like the hotel 
can operate equally well without his working which shows his incompetent, even feels out of touch with his coworkers (Stephen Balzac 2011).

To build their confidence to such employees, a way is to provide on-the-post training after they are hired. There is a strong link between training and employee retention after the research. Fresh employees who attend training are more easily to adapt the new working environment and know more about the management style of their boss and company (Rik Villegas 2006).

Communicate Regularly with Employees. Those employees, who lack confidence and trust on their boss and the future growth of the company, and the one who feel no one cares about their contributions to the company, may easily become depressed, dislodged and disoriented which lead their leave finally.

It is inversely proportional to workplace productivity that the hotel has too much employee turnover. Therefore, it is necessary to motivate and retain employees as much as possible to maintain the operation of a company. An approach that really helps guarantee employee retention is to talk with your staffs regularly to determine their working condition.

But how to determine that? Well, it is crucial to find out what's important to each employee and solve their different worries and concerns step by step. It is effective to talk with them and listen to their opinions actively-excellent bosses are usually attentive and good listeners (Office Communication Toolkit, 2009).

For instance, if an employee often asks you to give him feedback of his working performance, it means he needs to be recognized by the boss and the positive remarks from the boss valued more than a bonus or other material rewards. During the communication with such employees, you should let him know that all his contributions you have already aware, and his work is very important to the workplace productivity which his hard working match the company's long-term goals very well. In this kind of situation, the more you praise his contributions, the more committed and emotionally involved he will be (Hasan 2007).

For the ones who are not clear about their exact roles, responsibilities and their company's expectations, to state a clear-cut explanation of their precise roles and responsibilities from their employer is a better way. The clarifications help employees achieve their expected concentration and specific goals according to their own situation.

For the ones who don't quite convinced of you as their boss, it is your responsibility to show them that your firmness and enthusiasm for your work and the company, also you have a strong firm belief and a clear goal for the firm. Never let the misunderstanding of the employers from the employees lead to the uncertainty and distrust about the company's future. When employees have enough trust in their boss, they are more enthusiastic about their work and put more efforts on their own job which is also can make them happier.

For the ones lacking a sense of belonging and collaborating community, communicate and understand why he is reluctant to contact with others. Maybe he is a introverted person who is shy to talk, or some other reasons. Whatever causes his trouble, just try the best to help the employee overcome. As the leader, the employer should well understand a team was contribute by many people, the greater their loyalty to the whole team, the longer their retention span (Balzac, 2010).

Providing Competent Employees the Appropriate Salary and Benefits. "You can't do everything with money, but you can do nothing without it." As an old saying in my hometown, China, for those who face some really good jobs in the economy boom years, money is often the influential or even the top issue to concern when the talented employees decide whether they will stay on or leave. To prevent the temptation of your veteran employees to be attracted by tempting pay and appealing benefit packages offered by your competitors, you've got to do something to avoid your failure in the battle.

According to Fogleman's research, I believe that the employer needs to provide their stuffs working happiness and satisfaction by offering them proper or even pretty salaries and the benefits which are competitive in the market for retaining competent employees to ensure a company's healthy growth. Even the stock options can achieve the goal of the top talent who has made an indispensable contribution to the company and believes he has the right to share the profits of the 
company. An employee owned shares of the business will treat the business as his own, he will do his best to enable enterprises to gain more profits; for those who performs really good in their work, bonuses can be gave as recognition and prompt by the boss to appreciate his efforts; when the staff achieves the specified goal setting by the company, bonus can be used as incentives for his employer compensation; most of the employees are concerned about their survival, they retired, so that the pension for the older employees will make them feel safe and satisfied (Fogleman 2001).

Actually, all the inspiring methods it's not about money but the employer's concern for the welfare of the employees. For example, a working mother, if she can get a job which the employer allows her to follow a flexible working schedule so that she can take good care of her children when necessary, do you think she will be attracted by other job opportunities?

Employee Loyalty is Important in Hospitality Industry. Hospitality industry is an important part of local economy which has a wild range including most of the service industry. In order to maintain a healthy and stable development of the industry even in the economy boom years, the role of some older staffs in the hotel are very critical, especially experienced front-line staffs can play a stabilizing role in the industry. However, the most sever negative aspect which may impede their earnings growth and profitability is the high turnover rates. So the employers in all industries mostly concerned about employee retention and loyalty. The reason is simple: in the hotel industry, and even in all industries, the longer an employee works for an organization, the more valuable he is, and the more opportunities the hotel has among all the competitors in the same industry.

According to their research findings by Heskett and his research team, the following diagram came up with the Service Profit Chain Model in Harvard Business Review in 1994 as below:

\section{The Links in the Service-Profit Chain}

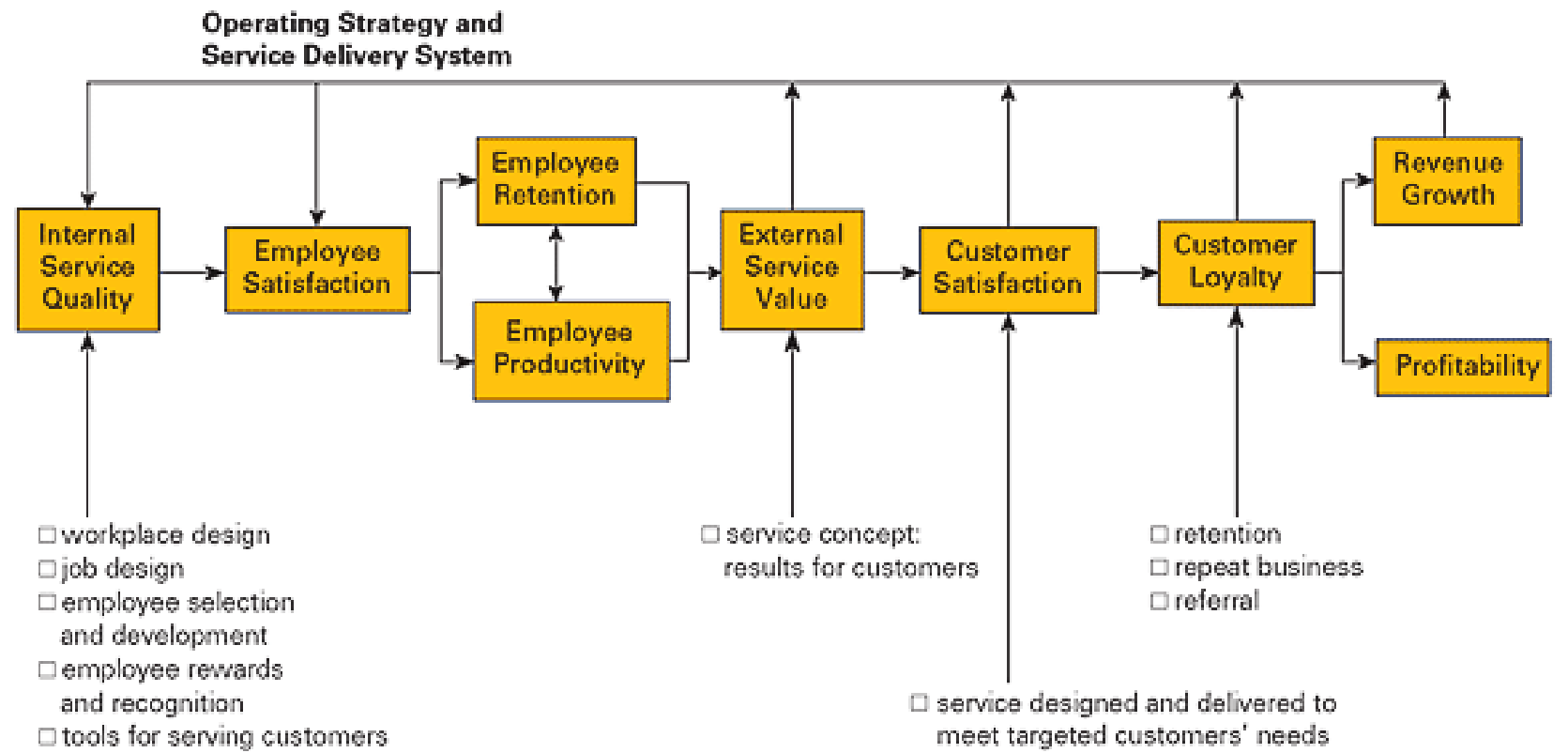

Figure 1. Service Profit Chain Model

The diagram illustrates that strong link between the internal service quality and the degree of employee satisfaction, that high internal promote the satisfaction of the employees, can bring long retention span and productivity improvement of the employee. Therefore, improving the value of external services and improving external services will increase customer satisfaction, which will help customer loyalty, while customer loyalty will lead to expected revenue growth and profitability. Since its publication, the model has been proved by a great deal of practitioners in service industry and scholars. 


\section{References}

[1] A. Jasna, A. Bostjan: International Journal of Management \& Information Systems, Vol. 15, (2011) .

[2] 3 Surefire Ways to Gain Employee Loyalty on http://www.openforum.com

[3] Employee Motivation on http://www.articlesbase.com

[4] The Role of HR in Talent Retention and Employee Loyalty on http://www.Factoidz.com

[5] Employee Loyalty: an Effective Solution for Labour Shortage on http: //www.thejournaloffranchise.com

[6] How To Improve Employee Loyalty on http://www. hrpeople.monster.com

[7] S. Balzac: Journal of Corporate Recruiting Leadership, (2011) No.7.

[8] A. Arbore , P. Guenzi and A. Ordanini: Journal of Service Management, Vol. 20 (2009) No. 3.

[9] Workers Antsy as Morale Plunges on http://www.usatoday.com/news

[10] Engaged Employees are Loyal Employees: Strategies to Help Cultivate a Sense of Fulfillment in Your Workforce on http://www.hcareers.com/us/resourcecenter 